Journal of Health Promotion and Behavior (2018), 3(4): 248-256

https://doi.org/10.26911/thejhpb.2018.03.04.04

\title{
Narration in Health Communication for Stunting
}

\author{
Scwarskof Turnip \\ Masters in Communication Sciences, Faculty of Social and Political Sciences, \\ Universitas Diponegoro
}

\begin{abstract}
Background: Globally, about 1 of 4 children under 5 years old was stunted. An estimated 80\% of 165 million stunted children live in 14 countries. Stunting and other forms of under nutrition reduce a child chance of survival, while also hindering optimal health and growth. Health communication is a key task in the worldwide to prevent the risk of stunting. This study aimed to describe the health communication for stunting prevention.

Subjects and Method: This was a qualitative case study. The theme of this study was health communication for stunting prevention. The data were collected by in-depth interview, observation, and document review. The data were analyzed using the notion of Narrative Theory and Health about theoretical thinking which explained the function of health narrative.

Results: A number of informative and persuasive efforts through the communication approach had been carried out by the Ministry of Health to reduce the number of people suffering from stunting. A number of communication and information media were used to convey information or persuasive messages related to stunting. Those media could help the public to understanding stunting and how to prevent or overcome it.

Conclusion: Health communication is important to help the public understand on how to prevent and overcome stunting.
\end{abstract}

Keywords: stunting, narrative theory and health, health communication

\section{Correspondence:}

Scwarskof Turnip. Masters Program in Communication Sciences, Faculty of Social and Political Sciences, Universitas Diponegoro. Email: Scwarskoft@gmail.com.

\section{BACKGROUND}

Stunting, or known as malnutrition, has become a phenomenon and problem that is considered globally, because it causes the growth (physical and brain) of children to be hampered, so that children can be short in stature. In Asia the number of children (toddlers) who suffer from stunting reaches 87 million children, in Latin America and the Caribbean there are 6 million children, and in Africa there are 59 million children (spread in West Africa 31.4 percent, Central Africa 32.5 percent, and East Africa 36.7 percent) 80 percent of 165 children who suffer from stunting live in 14 countries (Depkes, 2018).

In domestic areas, based on data compiled by the World Health Organization
(WHO), Indonesia ranks fifth in the number of stunting residents. WHO stipulates that the stunting tolerance limit is a maximum of 20 percent or one fifth of the total number of children under five. Meanwhile, Indonesia has 7.8 million children under five who suffer from stunting. This figure reaches 35.6 percent of the total number of toddlers as many as 23 million children at the beginning of 2018, which came from 2017. There were 18.5 percent of children categorized as very short and a total of 17.1 percent of children were short categories (Republika, 2018).

However, at the end of 2018 Health Minister Nila Farid Moeloek stated that stunting cases in Indonesia reached 37.2 percent (Tribunnews, 2018). 
Based on the records collected by the online news portal BeritaSatu.com, there are ten districts in Indonesia that are the priority of stunting treatment. These areas include Rokan Hulu (Riau), Central Lampung, Cianjur (West Java), Brebes and Pemalang (Central Java), Central Lombok (West Nusa Tenggara), Ketapang (West Kalimantan), Gorontalo (Gorontalo), Central Maluku (Maluku), and Lanny Jaya (Papua). However, the problem of stunting is not only experienced by people who are domiciled in rural areas or in less developed areas and who experience problems of poverty. Stunting is also experienced by people living in more developed urban areas. Data shows that 29 percent of babies born to wealthy families also experience stunting. In addition, 33 percent of babies born in urban areas suffer from stunting (Beritasatu, 2019). Phenomenon this shows that stunting cases tend to be a serious health problem for a number of individuals (children) in Indonesia.

Stunting is a manifestation of growth failure that begins in the womb, until the child is two years old (the first 1,00o days of birth). Prevention and control of stunting must begin right before birth and continue until the child is two years old. Child nutrition problems that cause stunting and malnutrition in pregnant women are often unknown or realized by individuals, families or the general public. The role of health workers including the community is important in disseminating nutrition at Posyandu or Puskesmas (Depkes, 2018).

Health is a combined state of physical, mental, and social well-being, which is not just an absence of disease (Littlejohn, 2017). In the context of this case, stunting has the potential to disrupt the growth of the body and brain of children, so that the community or parents are encouraged to understand stunting as a serious health problem for their children. Based on the results of a study from Ricardo in 2013 regarding stunting, it was found that toddlers suffering from stunting contributed to 1.5 million (15 percent) of child deaths in the world and caused 55 million children to lose their healthy life every year. Therefore, the community needs to understand the factors that have the potential to cause stunting. The factors that cause stunting cases are (Depkes, 2018):

1) Low access to nutritious food

2) Low intake of vitamins and minerals

3) Poor diversity of food and sources of animal protein

4) Mother's behavior and mother's caring for children in the provision of low nutrition

5) Adolescents who lack nutrition

6) Nutritional deficiencies during pregnancy and lactation

7) An infection occurs in the mother

8) Teen pregnancy

9) Mental disorders in the mother

10) Short birth spacing

11) Hypertension

On the other hand, stunting can also disrupt the achievement of quality Indonesian Human Resources and equitable economic growth. Based on the 2016 Human Development Report report, Indonesia's HDI in 2015 was ranked 113 out of 188 countries. This ranking has decreased from the previous period which was ranked 110. Meanwhile, according to data released by the OECD PISA, in 2012 Indonesian children's intelligence levels in the fields of reading, mathematics, and science were in 64th position from 65 countries. Indonesia lags behind Singapore (ranked 2), Vietnam (ranked 17), Thailand (ranked 50), and Malaysia (ranked 52).

Head of the National Development Agency, BambangBrodjonegoro revealed that stunting issues need to be watched out 
Journal of Health Promotion and Behavior (2018), 3(4): 248-256

https://doi.org/10.26911/thejhpb.2018.03.04.04

and prevented, so that by 2030 Indonesia will not receive a demographic bonus from the density of the population who suffer a lot from stunting. In the long term, stunting also has the potential to cause economic losses of 2-3 percent of the Gross Domestic Product (GDP) per year. Based on World Bank data in 2016, if Indonesia's GDP is IDR 13,000 trillion, the deficit that will be experienced will be IDR 260-390 trillion per year. When adults, children who are stunted also have an opportunity to earn 20 percent less than children who do not experience stunting (Liputan 6, 2018)

From the explanation above, it can be seen that one of the fundamental problems that arises is the ignorance of some Indonesian people regarding stunting and its effects, so that in the pattern of parental care for children they pay less attention to the proportion of nutrition and nutrition needed by mothers and children. Thus, the purpose of this study is to understand the strategy of communication through a number of popular media conducted by the Ministry of Health as parties or institutions that have authority and duties (main tasks and functions) specifically in the context of stunting prevention efforts that occur in the community.

\section{THEORETICAL THINKING}

This study uses the constructivist paradigm as a basis for theoretical thinking. According to Schwandt the constructivist approach emphasizes the world of experiences lived, felt, and experienced by social actors. In addition, he also emphasized that reality can be expressed through a variety of symbolic and language systems as well as being formed to ratify the implementation of a plastic character. Meanwhile, Guba and Lincoln tried to explain the constructivist approach by asking three questions; (1) what is the form and nature of reality (ontological question), (2) how is the nature of the relationship between the power and the known (epistemological question), and (3) how the researcher found out what he wanted (methodological question) (Denzin and Lincoln, 1994).

\section{Philosophical}

In this study, stunting problems were in the context of health communication or health communication, so to study communication strategies carried out by the Ministry of Health, Walter Fisher's Narrative Theory and Health was used. The basic assumption is the use of this theory that humans are homo narrants, who have tales or stories. Therefore, communicators who are in the frame of stunting issues, Ministry of Health will share stories related to the conditions they are experiencing.

\section{Assumptions of the Constructivist Approach}

\section{Constructivist Approach}

Ontology:

Relativist

Epistemology:

Transactional \&

Subjectivist

Methodology:

Hermeneutical

\& Dialectical
- reality can be understood as an invisible mental construction, based on specific experiences,

- the form and content of reality depends on the person or group that carries out the construction,

- construction is not more true or incorrect, but only more informed and or more sophisticated, or less informed and or less sophisticated,

- construction can change because it is a collection of reality.

\section{Researchers and research objects are assumed to be interactively connected}

The final goal is to screen an agreed upon and more sophisticated construction than the previous constructions. 
Health communication is an important element for prevention and treatment; which means an exchange of symbolic messages relating to the health of individuals, organizations and society. Personal or personal health is related to communication between family, friends, and providers of clinical or medical services such as doctors and nurses. Organizational aspects include the relationships that service providers have with each other. For example, we hope that our doctors will communicate effectively with those who carry out diagnostic tests (such as blood work) and specialists or hospitals where we might be referred. Public health communication includes media messages such as a public service announcement or health communication campaign (Littlejohn, 2017).

In AloLiliweri's notes explained that health communication is a systematic effort to positively influence the health behavior of individuals and the community, using various principles and methods of communication both interpersonal communication and mass communication (Liliweri, 2008). In the context of this case, the Ministry of Health seeks to use various means and mediums to transmit health messages to the public regarding stunting.

\section{Narrative Theory and Health}

Narrative is a key aspect of life. Walter Fisher described humans as homo narrants or inherent storytellers. In the context of health, the narrative describes what it means to be healthy or sick and the consequences of a disease and health. According to Fisher, narration is a different and equally valid way of thinking about human communication. The starting point is the nature of narration in humans. Universal functioning storytelling, natural human capacity that crosses time and culture; humans understand their actions and the actions of others in the form of stories. The purpose of narrative thinking is an understanding.

In the development of this theory, Sharf, Vanderford, Harter, and colleagues explained more specifically how narration operates and functions in the field of health and disease. First, the narrative is used as a sense-making process. When a person is diagnosed with a serious health condition, the narrative helps participants create meaning and helps explain uncertain circumstances. Usually, the process of making sense is done retrospectively when people retell the story. Second, the narrative is a way to assert control. When people are diagnosed with several health conditions, they experience loss of control. It may lose control literally (for example prostate cancer can cause bladder control problems), or it can mean giving up control of daily activities (such as doctors issuing prescriptions and scheduling tests, therapies, surgeries). Narration can help people reaffirm control in their lives. Third, narratives change identity. Narrative not only allows people to assert control, but also can function to improve and re-create their identity. Some health conditions result in changes in self-perception and role change.

Fourth, the narrative guaranteed decisions by showing certain choices and rationalizations. As long as health conditions change, many decisions must be made between current treatment options, current living conditions, and future steps to maintain health and welfare. Narratives display parastoryteller values and beliefs, which help the story-teller determine the right action. Listening to other people's stories also reveals the consequences of certain actions. Fifth, the narrative builded the community. People who experienced the same health challenges often felt a sense of friendship. They knew that there were other 
Journal of Health Promotion and Behavior (2018), 3(4): 248-256

https://doi.org/10.26911/thejhpb.2018.03.04.04

people who understand what they have been through and how it affected their lives.The stories they tell each other help strengthen this general perspective and help them learn from each other. The similarity that developed from storytelling was one reason why support groups were very important for people.

Narratives have function in a variety of ways and were important for providing insight into ourselves, our decisions about health and disease, and our health care. The story was what allowed us to understand, frame, and share our health experiences with others (Littlejohn, 2017).

\section{SUBJECTS AND METHOD}

This was a descriptive qualitative study. Case studies were used as research methods. Case studies allowed researchers to collect detailed information thoroughly from various dimensions about one particular case or a number of small cases. Cases might occur in an organization, a group of people or communities, events, processes and campaigns. Questions about what happened (what), how (how), and why (why) were the main concerns (Daymon and Holloway, 2002).

Chen and Pearce explained that the interpretation of the researcher was temporary, because the case study aimed to capture a picture of an event or situation that was contemporary in nature. Meanwhile, Denzin stated that case studies allow researchers to collect data from various sources or commonly referred to as data triangulation. Data for case studies can be obtained through interviews, observation, or document analysis (Denzin, 2005). In this study, interviews were conducted with employees of the Communication Bureau within the Ministry of Health of the Republic of Indonesia as those who knew and carried out directly various programs or public policies relating to stunting cases. While data from observations and documents were collected through the Ministry of Health's internal archives, official releases, and media articles relating to stunting cases.

\section{RESULTS \\ This study revealed that in the imple- mentation of national programs or policies on stunting carried out by the Ministry of Health, it was found that there were still many Indonesian people who did not know or understand the problem of stunting. They tend to be apathetic about the pattern of nurturing or providing nutrients needed by children. However, with the role of the Ministry of Health officer who routinely provided information on stunting and how to deal with it, both at the central and regional levels, the community gradually became aware of this health information. This national policy on stunting was carried out on National Nutrition Day, which was on January $25^{\text {th. }}$}

The issue of stunting has been the main topic at the National Health Work Meeting in February 2018. The Ministry of Health has became the 'main actor' in efforts to handle stunting nationally. In the process, the Ministry of Health involved a number of related institutions, namely the Coordinating Ministry for Human Development and Culture, the National Development Agency, and the Presidential Staff Office, thus encouraging more synergistic and effective performance in reducing stunting problems experienced by the community. The attention of the central government to stunting issues which tend to be the main agenda nationally, was not carried out in the previous administration era, therefore, the number of stunting patients in Indonesia exceeded the tolerance 
limit set by the World Health Organization (WHO) of 20 percent of the total children.

The Ministry of Health designed the national campaigns in the form of public service advertisements as 'health narratives' that can sensitize and persuade people through a number of media such as seminars, TV advertisements, television talk shows, radio talk shows (Elshinta), internet advertising (social media socializetion such as Instagram, Twitter, YouTube or Facebook), and optimized outdoor media such as the Jabodetabek electric train. Social media was used with a number of considerations such as based on the internet, having a relatively large number of users in Indonesia, and can be disseminated widely and quickly to others and relatively low-cost to the public. Even the Ministry of Health's Communication Bureau also optimized radio internet technology in disseminating its health messages through streaming radio called Radio Siaran Kesehatan. This internally managed radio was inaugurated on February 23, 2018, and can reach all the regions of Indonesia. The broadcast format of this radio was 50\% containing health information and news, 25\% health knowledge, and 25\% for entertainment and music, so that psychologically, it can reach listeners with a target age of 20-45 years old and SES (Social Economic Status) AB.

The core message that was disseminated was the prevention of stunting for the next generation and voiced to the public that the first 1000 days after the birth of a baby was an important time for fulfilling nutritional intake. In addition, the Ministry of Health also designed the campaign message "Fill My Plate" to socialize the proportion of ideal nutrients needed by human in one meal, namely $50 \%$ carbohydrates and 50\% vegetables and fruits. This concept can be applied flexibly in the area based on the wealth of local food.

Media discourse was also designed by the Ministry of Health to spread this stunting problem. In the form of talk shows, the process of disseminating information became more effective, because it can involve viewers to provide responses through interactive telephone services provided by media managers. A number of media were actively involved in this media discourse, NetTV, MetroTV, and INewsTV. Television was used with consideration as the main medium that was still used by Indonesian society in general.

\section{DISCUSSIONS \\ Pre national stunting handling prio- rity program}

The idea of expert thought Narrative Theory and Health explained that health narratives have five basic functions (Little John, 2017). Some Indonesian people have not yet realized and understood that stunting was a health problem that can have a negative impact on children's development, so it tend to affect the number of stunting patients in Indonesia who have exceeded the tolerance limit set by the World Health Organization (WHO) of 20\% total toddlers. The initial step taken by the Ministry of Health was to formulate a plan to 'promote' the term stunting nationally with a higher intensity of socialization than before. At the regional level, the prepared health narrative was to transform the term stunting with terms of malnutrition or malnutrition, so that it tend to be more easily understood by society. In an explanation of the thought ideas of Narrative Theory and Health, this initial step was intended to establish an understanding in the minds of the public that stunting was a serious problem for children and their long-term welfare. 
Journal of Health Promotion and Behavior (2018), 3(4): 248-256

https://doi.org/10.26911/thejhpb.2018.03.04.04

Health and disease were often socially constructed, which was how body conditions and psychology were perceived and imbued with social and cultural meanings. People focused on the social narratives that were shared socially, among the most common and strong forms of symbolic construction. Peter Berger and Thomas Luckmann explained that the construction of social reality was a dialectic between social reality and individual existence-in other words, symbolic tension between generally accepted knowledge and personal understanding (Thompson, 2003). The change in the term stunting to being malnourished or malnourished which was 'scanned' by the Ministry of Health to be shared with the public was intended as a sense-making process that was more familiar to public awareness and attention.

\section{National stunting management prio- rity program}

The issue of stunting has been the main topic at the National Health Work Meeting in February 2018. The Ministry of Health has become the 'main actor' in efforts to handle stunting nationally, involving the Coordinating Ministry for Human Development and Culture, National Development Agency, and the Presidential Staff Office, so that stunting prevention efforts can run more effectively. The national policy relating to stunting was carried out nationally at the commemoration of the National Nutrition Day, to further encourage public awareness about the importance of paying attention to the proportion of nutrition in the food consumed by children and pregnant women, thereby reducing the potential for stunting to emerge.

The Ministry of Health designed a national campaign in the form of public service advertisements as 'health narratives' that can sensitize and persuade the public through a number of media such as seminars, TV advertisements, television talk shows, radio talk shows (Elshinta), internet advertising (social media socialization such as Instagram, Twitter, YouTube, or Facebook), and optimize outdoor media such as the Jabodetabek electric train. Social media was used with a number of considerations such as being based on the internet, having a relatively large number of users in Indonesia, and can be disseminated widely and quickly to others and relatively low-cost for the public.

Based on research conducted by We Are Social (a British media company) in 2018, it was found that the average duration of Indonesian people using social media every day was three hours 23 minutes. Of the total population of 265.4 million, there were 130 million active social media users with $49 \%$ penetration (Tekno Kompas, 2018). Therefore, the use of social media as a way to campaign for national programs related to stunting, tend to be able to hit the public widely and quickly.

The borderless character which inherent in internet media, encouraged the Ministry of Health to optimize it as part of internal media that can be used to deliver national programs or policies on stunting. On February 23, 2018, the Ministry of Health Communication Bureau inaugurated a streaming radio called Radio Siaran Kesehatan, which can reach all regions in Indonesia. The broadcast format of this radio was $50 \%$ containing health information and news, $25 \%$ health knowledge, and $25 \%$ for entertainment and music, so that psychologically, it can reach listeners with a target age of 20-45 years old.

According to Pettigrew and Logan in Arianto (2013), health communication promoted health and disease in society, and made the system work optimally and effectively. As the main communicator who conducted message engineering to the 
public, the Ministry of Health focused on the dissemination of stunting prevention messages for the next generation and voices to the public that the first 1000 days of birth were the important times for fulfilling nutritional intake as the next step to establish a 'health system social 'prevention of stunting. In addition, the Ministry of Health also designed the campaign message "Isi Piringku" to socialize the proportion of ideal nutrition needed by humans in one meal, $50 \%$ of carbohydrates and $50 \%$ of vegetables and fruit, which was intended to improve nutrition experienced by children who suffer from stunting. This concept can be applied flexibly in the area based on the wealth of local food.

Media discourse was also designed by the Ministry of Health to spread this stunting problem. In the form of talk shows, the process of disseminating information became more effective, because it can involve the viewers to provide responses through interactive telephone services provided by media managers. A number of media were actively involved in this media discourse, NetTV, MetroTV, and INewsTV. Television was used with consideration as the main medium that was still used by Indonesian society in general.

\section{REFERENCES}

Arianto (2013). Komunikasi kesehatan: Komunikasi antara dokter dan pasien. Jurnal Ilmu Komunikasi UIN Surabaya.

Daymon C, Holloway I (2002). Qualitative Research Methods in Public Relations and Marketing Communications. USA: Routledge

Denzin, Norman K, Yvonna L (2005). The sage handbook of qualitative research: Third Edition. USA: Sage Publication
Depkes (2018). Penurunan stunting jadi fokus pemerintah. http://www.depkes.go.id/article/view/18050800004/penurunan-stunting-jadi-fokus-pemerintah.html.

Liliweri A (2008). Dasar-dasar komunikasi kesehatan. Jakarta: Pustaka Pelajar.

Littlejohn, Stephen W, Karen AF, John GO (2017). Theories of human communication: Eleventh Edition. Long Grove: Waveland Press Inc

Thompson, Teresa L, Alicia MD, Katherine IM, Roxanne P (2003). Handbook of health communication. New Jersey: Lawrence Erlbaum Associates, Inc

Republika (2018). WHO: 7,8 juta balita di indonesia penderita stunting. https://www.republika.co.id/berita/nasion al/umum/18/o1/24/p3os85396-who78-juta-balita-di-indonesia-penderita-stunting.

Tribun Kesehatan (2018). Empat dari 10 anak Indonesia alami stunting, menkes sebut negara rugi hingga ratusan triliun. http://www.tribunnews.com/kesehatan/2018/o8/o3/empat-dari10-anak-indonesia-alami-stuntingmenkes-sebut-negara-rugi-hinggaratusan-triliun.

Berita satu (2018). Stunting tinggal 30,8\%. https://www.beritasatu.com/kesehat an-aktualitas/518166-stunting-tinggal-308.html.

Depkes (2018). Ini penyebab stunting pada Anak. http://www.depkes.go.id/article/view/18052800oo6/ini-penyebab-stunting-pada-anak.html.

Liputan 6 (2018). Headline: Bahaya stunting dan ancaman lost generation, Indonesia harus berbuat apa?. https://www.liputan6.com/health/read/36 40739/headline-bahaya-stuntingdan-ancaman-lost-generationindonesia-harus-berbuat-apa. 
Journal of Health Promotion and Behavior (2018), 3(4): 248-256

https://doi.org/10.26911/thejhpb.2018.03.04.04

Tekno Kompas (2018). Riset ungkap pola

8/o3/o1/10340027/riset-ungkap-popemakaian medosis orang Indonesia. https://tekno.kompas.com/read/201 la-pemakaian-medsos-orang-indonesia. 